\title{
Effect of Growth Regulator and Ultra-Narrow Row (UNR) Spacing on Growth, Yield and Yield Components of Cotton
}

\author{
Sikander Hiyat ${ }^{1}$, Nazim Hussain ${ }^{1}$, Muhammad Ishaq Asif Rehmani ${ }^{2 *}$, Muhammad Nasir Abbas ${ }^{2}$, Smana \\ Raza $^{3}$, Javed Shabbir Dar ${ }^{4}$ and Tauqeer Ahmad Yasir ${ }^{5}$
}

${ }^{1}$ Department of Agronomy, Bahuddin Zakaryia University, Multan, Pakistan; ${ }^{2}$ Department of Agronomy, Ghazi University, Dera Ghazi Khan, Punjab, Pakistan; ${ }^{3}$ Department of Soil Science, Ghazi University, Dera Ghazi Khan, Punjab, Pakistan; ${ }^{4}$ Department of Agronomy, Shaheed Zulfiqar Ali Bhutto Agricultural College, Dokri, Pakistan; ${ }^{5}$ Department of Agronomy, SubCampus Layyah, Bahuddin Zakaryia University, Multan, Pakistan.

\begin{abstract}
Mepiquat chloride, widely used growth regulator in cotton fields to increase crop yield. The present study was performed to investigate the effects of growth regulator (mepiquat chloride) and row spacings on growth and yield attributes of cotton. The experiment was conducted on randomized complete block design (RCBD) with split plot arrangement. Three levels of row spacing $(25 \mathrm{~cm}, 50 \mathrm{~cm}$, and $75 \mathrm{~cm})$ were arranged in main plots, whereas, mepiquat chloride treatments (control, $\mathrm{MQC}_{0}$ ), mepiquat chloride 0.61 liter ha ${ }^{-1}$ ). Vegetative (plant height, number of monopodial and sympodial branches, no. of nodes plant ${ }^{-1}$ ) and reproductive growth and yield (no. of flowers plant ${ }^{-1}$, no. of square plant ${ }^{-1}$, no. of open and un-open bolls plant $^{-1}$, seed cotton yield and cotton seed yield) parameters were recorded. The results revealed that exogenous application of mepiquat chloride @ $0.61 \mathrm{~L} \mathrm{ha}^{-1}$, significantly reduced plant height as compared to control treatment. However, it did not reduce all other yield attributes of cotton. Among the row spacing treatments, widely spaced cotton plants $\left(\mathrm{RS}_{3}, 75 \mathrm{~cm}\right)$ without application of mepiquat chloride produced maximum seed cotton yield as compared to all other spacing levels. Ultra-narrow row spacing $\left(\mathrm{RS}_{1}, 25 \mathrm{~cm}\right)$ Combination of narrow row spacing $\left(\mathrm{RS}_{2}, 50 \mathrm{~cm}\right)$ and mepiquat chloride application slightly higher seed cotton yield. Ultranarrow row spacing must carefully use to exploit in the cotton production system was appeared to be a viable alternative approach for successful cotton production.

Received | December 16, 2018; Accepted | March 08, 2020; Published | August 01, 2020

*Correspondence | Muhammad Ishaq Asif Rehmani, Department of Agronomy, Ghazi University, Dera Ghazi Khan, Punjab, Pakistan; Email: dr.rehmani.mia@hotmail.com

Citation | Hiyat, S., N. Hussain, M.I.A. Rehmani, M.N. Abbas, S. Raza, J.S. Dar and T.A. Yasir. 2020. Effect of growth regulator and ultranarrow row (UNR) spacing on growth, yield and yield components of cotton. Pakistan Journal of Agricultural Research, 33(3): 561-569.

DOI | http://dx.doi.org/10.17582/journal.pjar/2020/33.3.561.569

Keywords | Cotton, Planting geometery, Mepiquat chloride, Row spacing, Phenology, Yield attributes
\end{abstract}

\section{Introduction}

$\mathrm{C}$ otton (Gossypium hirsutum L.) is major cash crop of Pakistan and excellent source of generating income on international platform (Amin et al., 2017; GoP, 2018; Sajjad et al., 2015). Cotton plant is unique in a sense that it contains perennial and indeterminate growth habit (Oosterhuis, 2001; Prewitt et al., 2018).
It plays a dynamic role in crop farming system, industrial level, employment, financial strength and economically feasibility in the country. Globally it provides raw material to the textile industries (Kili et al., 2005), spindles and units of oil expelling (Ahmad et al., 2009). Cotton crop is planted approximately in 76 major countries, that cover the area of $32 \mathrm{mha}$ of soil including the several ecological circumstances 
worldwide and world cotton trade is almost US \$21 billion yearly (Saranga et al., 2001). Cotton is the main source of crude oil and fiber material. it is fifth largest oil seed crop which covers the $40.0 \%$ need for the textile (APTMA, 2012) and 3.4\% of cooking oil correspondingly. In Pakistan it is main cash and fiber crop which is major source of foreign exchange and other agricultural products (Ali et al., 2009).

In cotton, ultra-narrow rows (UNR) spacings have been found to produce higher yield (14.4\%) as compared to the row spacing used in conventional type of production systems (Brodrick et al., 2010; Nawaz et al., 2016). UNR initially considered as a way of improving yield potential in lower production system where less plant population did not fully consume the planting area (Kerby et al., 1996; Nawaz et al., 2016). In a unit area yield potential is sustained due to the higher plant population in ultra-narrow row system (Lewis, 1971). In UNR system, yield component factor found that this was related to the high fruiting production per unit area in ultranarrow row system and that crop is related to the conventional crop system increasing in boll number per plant and ultimately production is effected by the available assimilates (Clawson, 2006).

Mepiquat chloride [N,N-1 dimethyl peridiniume chloride], a quaternary ammonium compound which is used as plant growth retardant, that has been commonly employed on cotton crop to alter its architecture and to increase fruit retention (Nawaz et al., 2019; Yan et al., 2019). Steve et al. (2003) reported that mepiquat chloride was introduced to the market in the late 1971's as plant growth regulator by decreasing the crop height, branch length, number of nodes, leaf area and suppress the excessive plant growth. Plant growth regulator effect the significant role in cotton production, as a result of optimizing input in cotton yield, under favorable sowing condition plants usually become highly vegetative and tall (Abbas et al., 2010). Plants of cotton treated with stance and mepiquat chloride (plant growth regulator) are usually more dense (McConnell et al., 1992), produce fewer reproductive branches, shortened internodes and have fewer nodes in plants (Stewart et al., 2001).

Application of mepiquat chloride on cotton crop usually gives the result in more dense plant (Nichols et al., 2003) resultant from less stem growth, minimum node formation, less growth of leaf, and also area of the leaf (Pettigrew and Johnson, 2005). Yield responses to mepiquat chloride application seem to be associated to environmental features encountered by the plant throughout the growing season. Favorable yield responses are most typically related with conditions that favor the maximum initial growth such as maximum rain fall, thick stand and high nitrogen rate. Uniform decrease in plant growth may be expected in conventional (Pettigrew and Johnson, 2005) and UNR cotton yield potential (Nichols et al., 2003), however, crop yield will be maximum (Biles and Cothren, 2001) is denied by investigation showing no feedback or no effect at all (Zhao and Oosterhuis, 2000).

Many techniques and different strategies for applying plant growth regulator to control plant height. The main aim of this research is to manipulate plant population and mepiquat chloride to restrict plant height and vegetative growth to improve yield.

\section{Materials and Methods}

To check the effect of different row spacing and application of mepiquat chloride on cotton crop, a field experiment was conducted at the Agronomic Research Area, Faculty of Agricultural Sciences and Technology, Bahuddin Zakaryia University, Multan, Pakistan $\left(71.50{ }^{\circ} \mathrm{E}, 30.26^{\circ} \mathrm{N}\right.$ and altitude $\left.123 \mathrm{~m}\right)$, during summer season of 2016. Experimental soil was sandy loam with $\mathrm{pH} 7.9$ and EC $1.5 \mathrm{dsm}^{-1}$, containing $702 \mathrm{ppm}$ total nitrogen, $3 \mathrm{ppm}$ total phosphorus, and $0.22 \mathrm{ppm}$ total potassium. The experiment was carried out under randomized complete block design with split plot arrangement. Experiment treatments including the row spacing were carried out three levels 25,50 and $75 \mathrm{~cm}$ at main plot. Sub plot was considered two levels of mepiquat chloride, control $\left(\mathrm{MQC}_{0}\right.$ water spray, without mepiquat chloride) and $0.61 \mathrm{~L} \mathrm{ha}^{-1} \cdot\left(\mathrm{MQC}_{1}\right)$. Each experimental unit was of net plot size $4.2 \times 10.04 \mathrm{~m}^{2}$.

In this experiment cotton cultivar Lalazar was used experimental material. Seed bed preparation was done by using cultivator followed by planking. Soil contained adequate moisture at the time of sowing. Seeds were manually sown. Plant population was maintained by gap filling (12 days after sowing) and thinning (21 days after sowing). Plant densities of $198000\left(\mathrm{RS}_{1}, 25 \mathrm{~cm}\right), 99908\left(\mathrm{RS}_{2}, 50 \mathrm{~cm}\right)$ and 65602 $\left(\mathrm{RS}_{3}, 75 \mathrm{~cm}\right)$ were recorded in different row spacing 
treatments. Local plant protection recommendations were followed to keep crop free of weeds, insects and diseases. Crop was irrigated as and when required to avoid moisture stress. Uniform crop management were applied for all experimental units, except treatments described above.

The crop was harvested in last week of October, 2016. Data were recorded on plant height $(\mathrm{cm})$, plant population $\left(\mathrm{m}^{-2}\right)$, densities of monopodial and sympodial branches plant ${ }^{-1}$, numbers of square, nodes and flowers plant ${ }^{-1}$, No. of nodes plant ${ }^{-1}$, flowers plant ${ }^{-1}$, bolls plant ${ }^{-1}$, open bolls plant ${ }^{-1}$, un-open bolls plant $^{-1}$, seed cotton yield $\mathrm{kg} \mathrm{ha}{ }^{-1}$, cotton seed yield $\mathrm{kg} \mathrm{ha} \mathrm{a}^{-1}$ and Lint yield $\mathrm{kg} \mathrm{ha} \mathrm{h}^{-1}$. First picking was done when $60 \%$ bolls were open and second harvesting was done after 20 days of first picking.

Data collected was analyzed statistically by using Fisher's analysis of variance (ANOVA) techniques with the help of Statistix 8.1 software. Duncan's multiple test (DMRT) was applied to separately treatments means at 5\% level of probability (Steel and Torrie, 1980).

\section{Results and Discussion}

\section{Plant height}

Results presented in Table 1 showed variations in cotton plant height when sown under varying row spacing and mepiquat chloride treatment. Among the different row spacing treatments, plants grown at wider row spacing $(\mathrm{RS}=75 \mathrm{~cm})$ were tallest and plant height gradually reduced with the reduction in row spacing. Application of mepiquat chloride caused significant reduction in the height of cotton plants as compared with the untreated plants, overall more than $13 \%$ reduction in plant height was observed with the treatment of mepiquat chloride $\left(0.61 \mathrm{~L} \mathrm{ha}^{-}\right.$ 1). Interaction of treatment showed that tallest plants (114.0) were produced when cotton plants were grown at widest row spacing and without application of mepiquat chloride $\left(\mathrm{RS}_{3} \times \mathrm{MQC}_{0}\right)$, whereas shortest plants $(95.47 \mathrm{~cm})$ were produced under UNR and mepiquat chloride treatment $\left(\mathrm{RS}_{1} \times \mathrm{MQC}_{1}\right)$.

Significant effect of mepiquat chloride and UNR was observed on plant height of cotton. Increased availability of nutrients, aerial space and better light penetration in the crop canopy to flourish to better partitioning of photo-assimilates and increasing metabolic activity resulting in taller in conventional space system as compared to UNR. Similar results were also predicted by Darawsheh et al. (2009), Saleem et al. (2009) and Lentz (2002). Similar reduction in plant height reductions of plant height associated with the mepiquat chloride application has been reported by Shahr and Mirshekar (2015).

Table 1: Effect of row spacing and mepiquat chloride on vegetative growth parameters of cotton.

$\begin{array}{lllll} & & \text { MQC }_{0} & \text { MQC } & \text { Mean } \\ \text { Plant height }(\mathrm{cm}) & \mathrm{RS}_{1} & 110.47 \mathrm{~b} & 95.47 \mathrm{c} & 102.97 \mathrm{~b} \\ & \mathrm{RS}_{2} & 110.93 \mathrm{~b} & 97.20 \mathrm{c} & 104.07 \mathrm{ab} \\ & \mathrm{RS}_{3} & 114.00 \mathrm{a} & 96.87 \mathrm{c} & 105.43 \mathrm{a} \\ \text { Plant population } & \mathrm{RS}_{1} & 23.33 \mathrm{a} & 20.33 \mathrm{~b} & 21.83 \mathrm{a} \\ \text { (m }^{-2} & \mathrm{RS}_{2} & 13.33 \mathrm{c} & 13.33 \mathrm{c} & 13.33 \mathrm{~b} \\ & \mathrm{RS}_{3} & 6.16 \mathrm{~d} & 6.16 \mathrm{~d} & 6.16 \mathrm{c} \\ \text { Monopodial branches } & \mathrm{RS}_{1} & 1.66 \mathrm{~d} & 1.40 \mathrm{~d} & 1.53 \mathrm{c} \\ \text { plant }^{-1} & \mathrm{RS}_{2} & 2.06 \mathrm{c} & 2.33 \mathrm{c} & 2.20 \mathrm{~b} \\ & \mathrm{RS}_{3} & 3.80 \mathrm{~b} & 4.26 \mathrm{a} & 4.03 \mathrm{a} \\ \text { Sympodial branches } & \mathrm{RS}_{1} & 6.46 \mathrm{~b} & 6.00 \mathrm{~b} & 6.23 \mathrm{~b} \\ \text { plant }^{-1} & \mathrm{RS}_{2} & 7.067 \mathrm{~b} & 7.00 \mathrm{~b} & 7.033 \mathrm{~b} \\ & \mathrm{RS}_{3} & 12.20 \mathrm{a} & 13.20 \mathrm{a} & 12.700 \mathrm{a} \\ & \mathrm{RS}_{1} & 1.066 \mathrm{~cd} & 0.86 \mathrm{~d} & 0.96 \mathrm{c} \\ & \mathrm{RS}_{2} & 2.00 \mathrm{c} & 1.86 \mathrm{~cd} & 1.93 \mathrm{~b} \\ & \mathrm{RS}_{3} & 4.40 \mathrm{~b} & 5.93 \mathrm{a} & 5.16 \mathrm{a} \\ & \mathrm{RS}_{1} & 70.00 \mathrm{c} & 69.33 \mathrm{c} & 69.67 \mathrm{c} \\ & \mathrm{RS}_{2} & 86.33 \mathrm{~b} & 83.87 \mathrm{~b} & 85.10 \mathrm{~b} \\ & \mathrm{RS}_{3} & 102.33 \mathrm{a} & 98.73 \mathrm{a} & 100.53 \mathrm{a}\end{array}$

$M Q C_{0}$ : without mepiquat chloride, Control; $M Q C_{1}$ : mepiquat chloride 0.61 liter $h a^{-1} ; R S_{1}$ : Row spacing $25 \mathrm{~cm} ; R S_{2}$ : Row spacing $50 \mathrm{~cm} ; R S_{3}$ : Row spacing $75 \mathrm{~cm}$.

\section{Plant population}

Plant population increased with the decrease in interplant spacing, therefore maximum plant population (21.83) was observed in UNR and decrease with increase in plant spacing reaching minimum (6.16) in wider rowed plants (RS3). Mepiquat chloride application showed non-significant influence on plant population $\left(\mathrm{m}^{-2}\right)$. Treatment interactions showed that maximum plant population density (23.33) was observed in cotton plants were grown without application of mepiquat chloride under $\mathrm{UNR}\left(\mathrm{RS}_{1} \times \mathrm{MQC}_{0}\right)$.

Niakan et al. (2012) and Sibert et al. (2006) also reported non-significant impact of mepiquat chloride application on population density, because it inhibits growth without causing plant mortality. Significant effect row spacing of plant population density can 
be attributed to plantation of more plants in UNR planting system. These findings are supported by previous studies carried by Zaxos et al. (2012) and Avgoulas et al. (2005).

\section{Cotton plant branches}

Data regarding monopodial branches plant ${ }^{-1}$ indicated that density of these branches decreases with reduction in row spacing (Table 1). Maximum number (4.03) of monopodial branches were produced in cotton plants grown at widest row spacing used in this study $\left(\mathrm{RS}_{3}\right)$ and minimum average was (1.53) was observed under UNR. Application of mepiquat chloride caused nonsignificant influence on production on monopodial branches. However, Interaction between mepiquat chloride $\times$ UNR was remained significant. Interaction of treatment showed that density of monopodial branches was maximum (4.26) were produced when cotton plants were grown at widest row spacing and treated with the mepiquat chloride $\left(\mathrm{RS}_{3} \times \mathrm{MQC}_{1}\right)$. Nichols et al. (2003) also reported non-significant effect of mepiquat chloride application on density of monopodial branches (plant $\left.{ }^{-1}\right)$. Significant variation among the production of monopodial branches under varying row spacing is in agreement with the previous reports (Clawson et al., 2006; Ferrari et al., 2014). They noted that conventional spaced plants sprayed with growth promoters gave more number of monopodial branches than UNR spaced cotton plant.

\section{Sympodial branches}

Impact on mepiquat chloride on density of sympodial branches (plant ${ }^{-1}$ ) remained non-significant (Table 1). Average density of sympodial branches was nonsignificantly higher (8.733) in mepiquat chloride treated plants as compared to untreated plants (8.576). However, row spacing significantly altered density of sympodial branches, which gradually decreased with decreasing row spacing. Density of sympodial branches was maximum (12.7) under conventional row spacing $\left(\mathrm{RS}_{3}\right)$ and minimum (6.23) under UNR. Interaction of treatment showed that maximum density of sympodial branches (13.2) was recorded in cotton plants grown at widest row spacing $\left(\mathrm{RS}_{3}\right)$ and treated with mepiquat chloride $\left(\mathrm{RS}_{3} \times \mathrm{MQC}_{1}\right)$.

Significant effect of UNR was observed on cotton that can be attributed to active uptake of nutrients to form photosynthates which actively translocated to different plant components and strengthening photosynthates supply for cell division and elongation of apical meristem in growing parts leading to better development of branches. These results are in agreement with the findings of Boquet (2005) and Donald (2005).

\section{Squares per plants}

Both mepiquat chloride and row spacing caused significant influence on the production on squares in cotton plants (Table 2). Maximum density of squares (5.16 squares plat ${ }^{-1}$ ) was obtained in $75 \mathrm{~cm}$ apart and minimum (0.96 squares plat $\left.{ }^{-1}\right)$ in UNR spacing $(25 \mathrm{~cm})$. Interaction of treatment showed that maximum square density (5.93) was recorded in cotton plants at widest row spacing $\left(\mathrm{RS}_{3}\right)$ and treated with mepiquat chloride $\left(\mathrm{RS}_{3} \times \mathrm{MQC}_{1}\right)$. Although density of squares is genetically controlled, however factors such as population density can influence. This finding is accordance with Sibert and Stewart (2006) and McConell et al. (1992). They documented that conventionally spaced cotton plant produced more numbers of squares as compared to UNR.

\section{Nodes perplant}

Application of mepiquat chloride showed nonsignificant influence on nodes (plant ${ }^{-1}$ ) (Table 2). However, row spacing showed significant effect on nodes. Maximum nodes (100.53) were obtained when cotton plants were grown at $75 \mathrm{~cm}$ spacing and minimum (69.67) in UNR treatment. Interaction of treatment showed that maximum nodes (102.33) were produced when cotton plants were grown at widest row spacing and without application of mepiquat chloride $\left(\mathrm{RS}_{3} \times \mathrm{MQC}_{0}\right)$. However, nodes were minimum (69.33) in plants grown at UNR and treated with mepiquat chloride $\left(\mathrm{RS}_{1} \times \mathrm{MQC}_{3}\right)$. Plant growth regulators promote cell multiplication and elongation help development of more branches on nodes (Iqbal et al., 2012). Khan et al. (2015) has given convincing proof of significant effect of UNR on nodes plant ${ }^{-1}$.

\section{Flowers}

Application of mepiquat chloride and UNR significantly influenced no. of flowers plant ${ }^{-1}$ compared with the untreated plant (Table 2). Considering the row spacing, maximum value of average density of flowers was observed in cotton plants grown at wider rows (RS3) which gradually reduced with decreasing row spacing, reaching minimum (0.333) under UNR (Table 2). Maximum number of flowers plant ${ }^{-1}(0.84)$ was obtained where mepiquat chloride was applied 
as compared to control treatment (0.67). Interaction of treatments indicated that flower density was the highest (1.2) in the cotton plants grown at conventional row spacing and treated with mepiquat chloride $\left(\mathrm{RS}_{3} \times \mathrm{MQC}_{1}\right)$ and minimum $(0.2)$ under UNR and without application of mepiquat chloride $\left(\mathrm{RS}_{1} \times \mathrm{MQC}_{0}\right)$.

Table 2: Effect of row spacing and mepiquat chloride on reproductive and yield parameters of cotton.

\begin{tabular}{|c|c|c|c|c|}
\hline & & $\mathrm{MQC}_{0}$ & MQC $_{1}$ & Mean \\
\hline \multirow{3}{*}{$\begin{array}{l}\text { No. of flowers plant } \\
-1\end{array}$} & $\mathrm{RS}_{1}$ & $0.200 \mathrm{e}$ & $0.466 \mathrm{~d}$ & $0.333 \mathrm{c}$ \\
\hline & $\mathrm{RS}_{2}$ & $0.733 c$ & $0.866 \mathrm{bc}$ & $0.800 \mathrm{~b}$ \\
\hline & $\mathrm{RS}_{3}$ & $1.066 \mathrm{ab}$ & $1.200 \mathrm{a}$ & $1.133 \mathrm{a}$ \\
\hline \multirow[t]{3}{*}{ No. of bolls plant ${ }^{-1}$} & $\mathrm{RS}_{1}$ & $4.40 \mathrm{~d}$ & $5.66 \mathrm{~d}$ & $5.03 c$ \\
\hline & $\mathrm{RS}_{2}$ & $7.66 \mathrm{c}$ & $8.60 \mathrm{c}$ & $8.13 b$ \\
\hline & $\mathrm{RS}_{3}$ & $19.80 \mathrm{a}$ & $16.86 \mathrm{~b}$ & $18.33 \mathrm{a}$ \\
\hline \multirow[t]{3}{*}{ Open bolls plant ${ }^{-1}$} & $\mathrm{RS}_{1}$ & $0.93 \mathrm{~b}$ & $0.93 \mathrm{~b}$ & $0.93 b$ \\
\hline & $\mathrm{RS}_{2}$ & $1.86 \mathrm{~b}$ & $1.26 \mathrm{~b}$ & $1.56 \mathrm{~b}$ \\
\hline & $\mathrm{RS}_{3}$ & $7.20 \mathrm{a}$ & $\mathrm{a}$ & $6.70 \mathrm{a}$ \\
\hline \multirow{3}{*}{${ }_{-1}^{\text {Un open bolls plant }}$} & $\mathrm{RS}_{1}$ & $3.46 c$ & $4.93 \mathrm{bc}$ & $4.200 \mathrm{c}$ \\
\hline & $\mathrm{RS}_{2}$ & $5.80 \mathrm{bc}$ & $7.33 \mathrm{~b}$ & $6.56 \mathrm{~b}$ \\
\hline & $\mathrm{RS}_{3}$ & $12.600 \mathrm{a}$ & $10.66 \mathrm{a}$ & $11.633 a$ \\
\hline \multirow{3}{*}{$\begin{array}{l}\text { Seed cotton yield } \mathrm{kg} \\
\mathrm{ha}^{-1}\end{array}$} & $\mathrm{RS}_{1}$ & $3576.5 b$ & $3521.0 \mathrm{~b}$ & $3548.8 \mathrm{a}$ \\
\hline & $\mathrm{RS}_{2}$ & $3362.5 b$ & $3740.8 \mathrm{ab}$ & $3551.7 \mathrm{a}$ \\
\hline & $\mathrm{RS}_{3}$ & $4108.2 \mathrm{a}$ & $3549.8 \mathrm{~b}$ & $3829.0 \mathrm{a}$ \\
\hline \multirow{3}{*}{$\begin{array}{l}\text { Cotton seed yield } \\
\mathrm{kg} \mathrm{ha}^{-1}\end{array}$} & $\mathrm{RS}_{1}$ & $2279.5 b$ & $2243.3 b$ & $2261.4 \mathrm{a}$ \\
\hline & $\mathrm{RS}_{2}$ & $2144.5 b$ & $2383.8 \mathrm{ab}$ & $2264.2 \mathrm{a}$ \\
\hline & $\mathrm{RS}_{3}$ & $2616.5 \mathrm{a}$ & $2262.5 b$ & $2439.5 \mathrm{a}$ \\
\hline
\end{tabular}

$M Q C_{0}$ : without mepiquat chloride; Control; $M Q C_{1}$ : mepiquat chloride 0.61 liter ha ${ }^{-1} ; R S_{1}$ : Row spacing $25 \mathrm{~cm}$; $R S_{2}$ : Row spacing $50 \mathrm{~cm} ; R S_{3}$ : Row spacing $75 \mathrm{~cm}$.

Application of mepiquat chloride significantly influenced no. of flowers plant ${ }^{-1}$ compared with the untreated plant. They result of present study is also in line with the conclusions of earlier studies carried by Abbas et al. (2010) and Iqbal et al. (2012). They noticed that plant with proper space have no competition on its basic growth necessities, whereas plants grown at shorter row spacing experiences interplant competition leading to variations in production of flowers. Less no. of flowers plant ${ }^{-1}$ was due to plants competition for light, nutrients, water and space due to inters specific competition causing less flowering. These results are in line with Killi et al. (2016) and Nuti et al. (2008) they reported production of fewer flowers in UNR as compared to conventional spacing.
Bolls

The data (Table 2) indicated non-significant result of mepiquat chloride on density of bolls (plant ${ }^{-1}$ ). However, row spacing significantly affected boll density of cotton plants. Density of bolls was maximum (18.33) in the plants when spaced $75 \mathrm{~cm}$ apart and decreased significantly with decreasing row spacing, reaching lowest (5.03) under UNR treatment. Interaction between mepiquat chloride and row spacing was also significant. Considering treatment interaction, maximum bolls (19.8) were produced when cotton plants were grown at widest row spacing and without application of mepiquat chloride $\left(\mathrm{RS}_{3} \times \mathrm{MQC}_{0}\right)$. Contrarily minimum bolls (4.4) were produced on plants grown at UNR without mepiquat chloride treatment $\left(\mathrm{RS}_{1} \times \mathrm{MQC}_{0}\right)$.

Number of bolls plant per plant is a critical yield contributing parameter to assess the yield of seed cotton (Feng et al., 2017). The data of current study indicated non-significant result of mepiquat chloride on number of bolls (plant ${ }^{-1}$ ) as reported by Rethwisch et al. (2010) and Bibi et al. (2012). However, UNR spacing affected significantly on no. of bolls (plant ${ }^{-1}$ ). Increase in number of bolls plant ${ }^{-1}$ is due to increased yield potential of fruiting points and declined in shedding of floral parts as a result of increased meristematic activity by auxin as reported by Quigley et al. (2015) and Brodrick et al. (2010).

Data about production of open bolls showed that treatment of mepiquat chloride had no significant influence on production of open-bolls. However, significant influence of row spacing on open bolls plant $^{-1}$ was observed. Maximum open bolls (6.7) were observed in plant when spaced $75 \mathrm{~cm}$ apart as compared UNR (0.93), which was statistically similar with the open-bolls produced under $\mathrm{RS}_{2}$ (1.56). Interaction of treatments showed that density of open bolls was maximum (7.2) produced in the experimental plot with wider row spacing and mepiquat chloride treatment $\left(\mathrm{RS}_{3} \times \mathrm{MQC}_{0}\right)$. However, minimum density of bolls (0.93) was produced in plants grown at UNR without any influence of mepiquat chloride application $\left(\mathrm{RS}_{1} \times \mathrm{MQC}_{0} / \mathrm{MQC}_{1}\right)$.

The impact of mepiquat chloride showed no effect on number of open bolls plant ${ }^{-1}$ significantly, consistent with the results reported earlier (Yeats et al., 2002; Stewart et al., 2001). They reported non-significant result of mepiquat chloride on no. of bolls plant ${ }^{-1}$. 
Conventional plant spacing showed significant effect on open bolls plant ${ }^{-1}$ as compared to UNR. The results of current study also in favor with the findings of previous of studies carried by Ali et al. (2010) and Cheema et al. (2004) they noted that conventional spacing produced more number of open bolls plant ${ }^{-1}$ than UNR.

Similar to the total bolls and open-bolls, density of un-opened bolls was also significantly influenced by row spacing. Maximum density of un-open bolls (11.63 plant $^{-1}$ ) obtained where $75 \mathrm{~cm}$ spacing was kept as compared to UNR producing fewest (4.20) un-open bolls. Interaction of treatments showed that maximum density of un-open bolls (12.6) was recorded in the cotton plants grown at widest row spacing without mepiquat chloride application $\left(\mathrm{RS}_{3} \times \mathrm{MQC}_{0}\right)$. Minimum density of un-open bolls (12.6) was found in the cotton plants grown at UNR spacing without mepiquat chloride treatment $\left(\mathrm{RS}_{1}\right.$ $\times \mathrm{MQC}_{0}$ ). Current study shows non-significant effect of both mepiquat chloride and plant spacing on no. of un-open bolls plant ${ }^{-1}$ as reported by Iqbal and Islam (2007). Similar results were presented by Larson et al. (2004) and Jost and Cothren (2001) as they reported fewer un-open bolls were produced as compared to conventionally sown cotton.

\section{Cotton yield}

Data on seed cotton, cotton seed yield $\left(\mathrm{kg} \mathrm{ha}{ }^{-1}\right)$ indicated non-significant influence of mepiquat chloride, UNR spacing and interactive result of mepiquat chloride $\times$ UNR on seed cotton yield $\left(\mathrm{Kg} \mathrm{ha} \mathrm{h}^{-1}\right)$ (Table 2). This result is in line with those of Balkcom et al. (2010), Nichols et al. (2003) and Boquet (2005). They reported non-significant differences of application of mepiquat chloride, UNR spacing and their interactive effect on seed cotton, cotton seed and lint yield. Data collected on cotton seed, seed cotton and lint yield $\left(\mathrm{kg} \mathrm{ha}^{-1}\right)$ showed that effect of application of mepiquat chloride and UNR remained non-significant. Iqbal and Islam (2007) and Gwathmey et al. (2010) also reported non-significant effect of mepiquat chloride and UNR on bolls plant ${ }^{-1}$ respectively. Although application of mepiquat chloride reported to decrease cotton yield under late planting (Tung et al., 2018).

\section{Conclusions and Recommendations}

Based on results presented in current study it is concluded that application of mepiquat chloride proved effective to control the vegetative growth of cotton plant in order to accelerate reproductive growth. It caused shorter plants height and maximum bolls and increased seed cotton yield. Cotton grown at ultra-narrow row spacing of $75 \mathrm{~cm}$ spaced plants flourished more and bear maximum fruits and yield ultimately. Hence the application of mepiquat chloride on $75 \mathrm{~cm}$ spaced grown plant is proved to be effective in order to improve cotton yield. Conclusion made from this experiment is, in regard to obtain potential lint yield and fiber quality, application of plant growth regulators and ultra-narrow row systems was appeared to be a viable alternative approach for successful cotton production.

\section{Acknowledgement}

No financial support was obtained to conduct this study.

\section{Author's Contribution}

Sikander Hiyat: Conceived the idea, designed and conducted the study, analyzed data, wrote initial draft of manuscript. Nazim Hussain: Conceived the idea, designed, supervised and managed the study. $\mathrm{Mu}-$ hammad Ishaq Asif Rehmani: Monitored experimentation, analyzed the data, wrote and revised the manuscript. Muhammad Nasir Abbas and Smana Raza: Assisted experimentation and data collection. Javed Shabbir Dar: Technical input, writing and revision of manuscript. Tauqeer Ahmad Yasir: Performed data analysis and participated in manuscript writing (results and Discussion).

\section{Conflict of interest}

There is no conflict of interest.

\section{References}

Abbas, G., G. Hasaan, M. Aslam, I. Hussain and U. Saeed. 2010. Cotton response to multiple application of growth inhibitor (Mepiquat chloride). Pak. J. Agric. Sci. 47(3): 195-199.

Ahmed,A.,U.H.R.Ali,S.I.Zamir and N.Mehmood. 2009. Growth, yield and quality performance of cotton cultivar BH-160 (Gossypium hirsutum L.). J. Anim. Plant Sci., 19(4): 189-192.

Ali, A., M. Tahir, M. Ayub, I. Ali, A. Wasaya and F. Khalid. 2009. Studies on the effect of plant 
spacing on the yield of recently approved varieties of cotton. Pak. J. Life Soc. Sci. 7(1): 25-30.

Ali, M., L. Ali, M. Sattar and M. Anjum. 2010. Response of seed cotton yield to various plant population and planting method. J. Agric. Res. 48(2): 164-169.

Amin, A., W. Nasim, M. Mubeen, M. Nadeem, L. Ali, H.M. Hammad, S.R. Sultana, K. Jabran, M.H.U. Rehman, S. Ahmad, M. Awais, A. Rasool, S. Fahad, S. Saud, A.N. Shah, Z. Ihsan, S. Ali, A.A. Bajwa, K.R. Hakeem, A. Ameen, Amanullah, H.U. Rehman, F. Alghabar, G.H. Jatoi, M. Akram, A. Khan, F. Islam, S.T. Ata-U1Karim, M.I.A. Rehmani, S. Hussain, M. Razaq and A. Fathi. 2017. Optimizing the phosphorus use in cotton by using CSM-CROPGROcotton model for semi-arid climate of VehariPunjab, Pakistan. Environ. Sci. Pollut. Res. 24(6): 5811-5823. https://doi.org/10.1007/s11356016-8311-8

APTMA. 2012. World cotton and non-cotton fiber consumption. available online at http://www. aptma.org.pk/Pak_Textile_Statistics/ repo.asp.

Avgoulas, C.,L.Bouza, A. Koutrou, S. Papadopoulou, S. Kosmas, E. Makridou, P. Papastylianou and D. Bilalis. 2005. Evaluation of five most commonly grown cotton cultivars (Gossypium birsutum L.) under Mediterranean conditions: productivity and fibre quality. J. Agric. Crop Sci. 191: 1-9. https://doi.org/10.1111/j.1439037X.2004.00139.x

Balkcom, K.S., A.J. Price, E. Van Santen, D.P. Delaney, D.L. Boykin, F.J. Arriaga, J.S. Bergtold, T.S. Kornecki, R.L. Raper. 2010. Row spacing, tillage system, and herbicide technology affects cotton plant growth and yield. Field Crops Res. 117(2): 219-225.

Biles, S.P and J.T. Cothren.2001. Flowering and yield response of cotton to application of mepiquat chloride and PGR-IV. Crop Sci. 41: 1834-1837. https://doi.org/10.2135/cropsci2001.1834

Boquet, D.J., 2005. Cotton in ultra-narrow row spacing; plant density and nitrogen fertilizer rates. Agron. J. 97: 279-287. https://doi.org/10.2134/ agronj2005.0279

Brodrick, R., M.P. Bange, S.P. Milroy and G.L. Hammer. 2010. Yield and maturity of ultranarrow row cotton in high input production systems. Agron. J. 102(3): 843-848. https://doi. org/10.2134/agronj2009.0473

Cheema, M.S., M. Afzal and M.S. Ahmad. 2004.
Effect of sowing date on seed cotton yield (Gossypium birsutum L.) under Bahawalpur conditions. J. Agric. Res., 26: 177-179.

Clawson, E.L., J.T. Cothren and D.C. Blouin. 2006. Nitrogen fertilization and yield in Evaluation of seed cotton (Gossypium hirsutum L.) production and quality in relation to the different irrigation levels and two row spacings. Int. J. Plant Prod. 6 (1): 129-114.

Darawsheh, M.K., E. Khah, M. Aivalakis, G. Chachalis and D. Sallaku. 2009. Cotton row spacing and plant density cropping systems I. Effects on accumulation and partitioning of dry mass and LAI. J. Food Agric. Environ. 7: 258261.

Donald, J.B., 2005. Cotton in ultra-narrow row spacing; plant density and nitrogen fertilizer rates. J. Agron. 96: 279-286. https://doi.org/10.2134/ agronj2005.0279

Feng, L., J. Dai, L. Tian, H. Zhang, W. Li and H. Dong. 2017. Review of the technology for highyielding and efficient cotton cultivation in the northwest inland cotton-growing region of China. Field Crops Res. 208: 18-26.

Ferrari, J.V., E.F. Júnior, S. Ferrari, A.P.P.G. Luques, D.M.A. Santos and F.M. Benke. 2014. Growth and cotton yield over row spacing and growth regulator. Rev. Bras. Ciênc. Agrár. Recife. 9(3): 359-364.

https://doi.org/10.5039/agraria. v9i3a3658

GOP. 2018. Economic survey, ministry of food, agriculture and livestock (Federal Bureau of Statistics), Islamabad, pp. 11-26.

Gwathmey, C.O. and J.D. Clement. 2010.Alteration of cotton source sink relations with plant population density and mepiquat chloride. Field Crops Res. 116(1): 101-107. https://doi. org/10.1016/j.fcr.2009.11.019

Iqbal, H.M. and N.U. Islam. 2007. Cotton response to mepiquat chloride and nitrogen under ultra narrow plant spacing. Asian J. Plant Sci., 6: 8792. https://doi.org/10.3923/ajps.2007.87.92

Iqbal, M., S. saghir, W. Nazeer, T. Muhammad, M. Bismillah, M. Mubshar, A. Mehmood., M. Tauseef, A. Hameed and A. Kareem. 2012. High plant density by narrow plant spacing ensures cotton productivity in elite cotton (Gossypium birsutum L.) genotypes under severe cotton leaf curl virus (CLCV) infestation. Afr. J. Biotecnol. 11(12): 2869-2878. https://doi.org/10.5897/ AJB11.3259 
Jost, P.H. and J.T. Cothren. 2001. Phenotypic alterations and crop maturity differences in ultra- narrow row and conventionally spaced cotton. Crop Sci. 41: 1150-1159. https://doi. org/10.2135/cropsci2001.4141150x

Kerby, T.A., B.L. Weir and M.P. Keeley. 1996. Narrow-row production. In: Hake, S.J., Kerby, T.A., Hake, K.D. (Eds.), Cotton production manual. Univ. California, Oakland, pp. 356-364.

Khan, N., K. Usman, F. Yazdan, S.U. Din, S. Gull, S. Khan. 2015. Impact of tillage and intra-row spacing on cotton yield and quality in wheatcotton system. Archives of Agronomy and Soil Science. 61(5): 581-597.

Killi, F., L. Efe and S. Mustafayev. 2005. Genetic and Environmental Variability in Yield, Yield Components and Lint Quality Traits of Cotton. Int. J. Agric. Biol., 7(6): 1007-1010.

Killi, F., M. Ozdemir and F. Tekeli. 2016. Cotton sown in different row distances after wheat harvest: seed cotton yield and yield components. Int.J.Environ. Agric. Res., 2 (8): Issue-8, August2016.

Larson,J.A., C.O.Gwathmey, R.K.Roberts and R.M. Hayes. 2004. Economics and Marketing. Effects of plant population density on net revenues from ultra narrow row cotton. J. Cotton Sci., 8: 69-82.

Lentz, J. 2002. Overview of ultra narrow row cotton. J. Nat. Resour. Life Sci. Educ. 31: 70-72.

Lewis, H.L., 1971. What is narrow row high population cotton. Cotton Ginners J. Yearbook March: 49.

McConnell,J.S., W.H. Baker, B.S. Frizzell, J.J. Varvil. 1992. Response of cotton to nitrogen fertilization and early multiple applications of mepiquat chloride. J. Plant Nutr. 15(4): 457-468.

Nawaz, H., N. Hussain, A. Yasmeen, S.A.H. Bukhari and M.I.A. Rehmani. 2019. Ultra-narrow row spacing: a sustainable and economical approach ensuring profitable cotton production. Pak. J. Agric. Sci. 56: 101-107.

Nawaz,H., N.Hussain,M.I.A.Rehmani,A.Yasmeen and M. Arif. 2016. Comparative performance of cotton cultivars under conventional and ultranarrow row (UNR) spacing. Pure Appl. Biol. 5(1): 15-25.

Niakan, M., A. Habibi and M. Ghorbanli. 2012. Study of Pix regulator effect on physiological responses in cotton plant. Sch. Res. Libr. Ann. Biol. Res., 3(11): 5229-5235.

Nichols, S.P., C.E. Snipes and M.A. Jones. 2003.
Evaluation of row spacing and mepiquat chloride in cotton. J. Cotton Sci., 7: 148-155.

Nuti, R.C., R.P. Viator, S.N. Casteel, K.L. Edmisten and R. Wells. 2006. Effect of planting date, mepiquat chloride, and glyphosate application to glyphosate-resistant cotton. Agric. J., 98: 16271633. https://doi.org/10.2134/agronj2005.0360

Oosterhuis, D., 2001. Physiology and nutrition of high yielding cotton in the USA. Informaçõesagronômicas. 95: 18-24. https://doi. org/10.1081/PLN-100104969

Pettigrew, W.T and J.T. Johnson. 2005. Effects of different seeding rates and plant growth regulators on early-planted cotton. J. Cotton Sci., 9: 189-198.

Prewitt, S.F., B.G. Ayre and R.C. McGarry. 2018. Cotton CENTRORADIALIS/TERMINAL FLOWER 1/SELF-PRUNING genes functionally diverged to differentially impact plant architecture. J. Exp. Bot. 69(22): 54035417.https://doi.org/10.1093/jxb/ery324

Quigley, R.A., D. Tan and R. Brodrick. 2015. Effect of $1 \mathrm{~m}$ and $1.5 \mathrm{~m}$ row spacing on yield and fibre quality of upland cotton (Gossypium birsutum) in Warren, NSW, Australia. Building Productive, Diverse and Sustainable Landscapes, 17th Australian Agronomy Conference, 20-24 September 2015, Hobart, Australia. Conference Proceedings. Australian Society of Agronomy Inc, pp. 235-238.

Rethwisch,M.D.,T.Cox,D.M. Ramos,M.Luna and J. Wellman. 2006. Effects of Goëmar ${ }^{\circledR}$ BM86 and Mepiquat Chloride on DPL 449BR/DPL 494R Cotton. Cotton: A College of Agriculture and Life Sciences Report. az1409: P-145.

Sajjad, A., A. Imran, S. Akbar and A.H. Makhdum. 2015. Current Trends of decent work in cotton ginning small and medium enterprises of Pakistan. J. Environ. Agric. Sci. 2: 10.

Saleem, M.F., S.A. Anjum, A. Shakeel, M.Y. Ashraf and H.Z. Khan. 2009. Effect of row spacing on earliness and yield in cotton. Pak. J. Bot., 41: 2179-2188.

Saranga, Y., M. Menz, C.X. Jiang, J.W. Robert, D. Yakir and H.P. Andrew. 2001. Genomic discussion of genotype $\mathrm{x}$ environment interaction conferring adaptation to arid condition. Genomic Res. 11: 1988-1995. https://doi.org/10.1101/ gr.157201

Shahr, H.A.M. and B. Mirshekari. 2015. Effect of hormonal growth regulator spraying and topping 
on some agronomic traits in the newly released cotton (Gossypiumbirsutum) cultivars. Int. J. Adv. Life Sci. 8(2): 115-120.

Siebert, J.D., A.M. Stewart and B.R. Leonard. 2006. Comparative growth and yield of cotton grown at various densities and configurations. Agron. J. 98: 562-568. https://doi.org/10.2134/ agronj2005.0181

Steel, R.G., J.H. Torrie. 1980. Principles and Procedures of Statistics McGraw-Hill Book Co. Inc., New York. 481.

Steve, P., Nichols, E. Charles, Snipes and A.M.Jones. 2003. Evaluation of row spacing and mepiquat chloride in cotton. J. Cotton Sci. 7: 148-155.

Stewart, A.M., K.L. Edmisten and R. Wells. 2001. Wick applicator for applying mepiquat chloride on cotton: I. Rate response of wick and spray delivery systems. J. Cotton Sci. 98: 72-79.

Tung, S.A., Y. Huang, S. Ali, A. Hafeez, A.N. Shah, X. Song, X. Ma, D. Luo and G. Yang. 2018. Mepiquat chloride application does not favor leaf photosynthesis and carbohydrate metabolism as well as lint yield in late-planted cotton at high plant density. Field Crops Res. 221: 108-118. https://doi.org/10.1016/j.fcr.2018.02.027

Yan, W., M. Du, W.Zhao, F. Li,X.Wang, A.E. Eneji, F. Yang, J. Huang, L. Meng, H. Qi, G. Xue, D. Xu, X. Tian and Z. Li. 2019. Relationships between plant architecture traits and cotton yield within the plant height range of $80-120 \mathrm{~cm}$ desired for mechanical harvesting in the Yellow River Valley of China. Agronomy. 9(10): 587. https://doi. org/10.3390/agronomy9100587

Yeates, S.J., G.A. Constable and T. McCumstie. 2002. Developing management options for mepiquat chloride in tropical winter season cotton. Field Crops Res. 74: 217-230. https:// doi.org/10.1016/S0378-4290(02)00005-9

Zaxos,D.,S.Kostoulaa,E.M.Khaha,A.Mavromatisa, D. Chachalisb and M. Sakellariou. 2012. Evaluation of seed cotton (Gossypium birsutum L.) production and quality in relation to the different irrigation levels and two row spacings. Int. J. Plant Prod. 6 (1): 129-114.

Zhao, P. and D.M. Oosterhuis. 2000. Pix plus and mepiquat chloride effects on physiology, growth, and yield of cotton.J.Plant Growth Reg. 19: 415422. https://doi.org/10.1007/s003440000018 